\title{
Application of Objectivism in American Literature Teaching
}

\author{
Shaojun Duan* \\ School of Foreign Languages \\ Kunming University \\ Kunming, China \\ duanshaojun2709@126.com
}

\begin{abstract}
William Carlos Williams succeeded and earned his fame by breaking the tradition in literature, forming his own unique writing style, that is, objectivism, which made him, became an extraordinary poet in American history. Williams' three main characteristics of objectivism include seeking for expressing ideas in objective things, experiencing objects by senses, and taking advantages of skills used in western paintings. If teachers can guide students to apply this theory into analysis of Williams' poems in American literature teaching, students would have a profound understanding about the poet and his poems from a new and interesting angle. This article puts forward a good example by choosing Williams' six poems to analyze the objectivism embodied in them.
\end{abstract}

Keywords-American literature teaching; objectivism; William Carlos Williams; poems

\section{INTRODUCTION}

As the prominent poet in American literature history, William Carlos Williams created a new method of writing poems which had a great effect on the Black Mountain School and the New York School. Ginsberg once said it is Williams who liberated his voice of poetry. In early period he mainly depended on imitation, and Yeats is his model. Later influenced by the famous imagism poet Pound, he began to create imagism poems. However, based on the inner love for his country, he turned to use common words to describe the life of American citizens. In writing poems he gradually led the fashion trend of objectivism: Seeking for expressing ideas in objective things and experiencing objects by senses make readers feel the beauty of other senses instantly while reading the poems. Besides he took advantages of western painting creative approaches boldly. In the 1950s Williams' poems won the National Book Award and Bollingen Award for Poetry; in 1962 he won the Pulitzer Award. This paper tries to establish a good example for teachers to imitate to teach students to apply theory into practise in American literature teaching class by choosing Williams' six poems to analyze the objectivism embodied in them. Before practise, it's better for teachers to lead students to learn the theory of objectivism put forward by Williams first.

\section{The OBJECTIVISM OF WILLIAMS}

Being one of the most important poets in American literature history Williams has drawn enormous attention from scholars both in China and abroad.

In China, some scholars put their attention in Williams' early creating period that is the intimating period. During this time he met Pound so there are also many articles that tell the relationship between the two famous poets. In 1993, Zhang Yuejun(1999) published an article named 'Williams' Yeats Era”. In it the writer traced the influence that Yeats's poetry creation on Williams, especially the big influence on Williams' early poetry creation. The article wrote by Hong Zhenguo (1993) talks about Williams' change in creating skills after imitating period, then forming his own style and carrying it forward bravely. There are also some scholars who are interest in his visual writing skills. Yu Meijun(2006) thinks this has a big connection with his mother who learnt painting for about three years but stopped for lack of money. In many of his poems such as "The Red Wheelbarrow", we can see the skills used in painting. When seeing this kind of poem it's not only the simple words but also the colorful visual effect that make people feel impressive. Also in another article wrote by Huyu(2011) analyzed the cubism painting characteristics in Williams' poems. Other researches are about Williams' relationships with China and some old Chinese poems. For example, Huli (2011) showed us some poems Williams translated together with Wang Dawei. In Williams' poem “The Widow's Lament in Spring” we can feel the familiarity from Chinese poems. In Zhang Yuejun's (2001) article, he showed us Williams' love for Chinese culture and also the love for his own country. He brought Chinese culture to America in an early time.

In abroad, H. Waggoner Hyatt (1968) thinks highly of Williams' writing skills. When commenting Williams' poetry, he says, "his poetry is the 'instant picture' of things, people or scenes of everyday life, what he showed to us is direct things we see, original poetry materials, without explanation or comments. Also at this point, James D. Hart (1983) shares the same opinion with him. He perceives the great technique using in the poems. When reading Williams' poems he finds the brief but meaningful pictures, he even feels the open passion in them. The poet wrote poems according to his specific experience, he observed carefully, expressed vividly which make a 
harmonious scene in our mind. Limn (1986) pays more attention to his creating in the way of writing poems. He thinks the objectivism poem is not like music but more like sculpture. The poem erects a plaster-like image and gives it to the reader. In “Autobiography of the Works of a Poet," Edith Heal (1977) tells us the motivation that forces Williams to create the new way. After reading “The Waste Land” he found Eliot deserted America, but Williams refused to be deserted, so he had fierce reaction. He thought it would affect the following poets and bring them from his circle. So he tried to create a new way to write poems, a future form which makes the contemporary poets can't match. In the end he succeeded and earned his fame by breaking the tradition in literature which made him became an extraordinary poet in American history.

From above domestic and foreign researches, we can find out that the articles about Williams' objectivism have already been mentioned and discussed. In the following part, three features of Williams' objectivism will be summarized and listed out for students to learn.

\section{A. Looking for expressing ideas in objective things}

To look for expressing ideas in objective things, just as the poet himself said "thinking only resides in the thing itself, that is, no ideas but in things", which is also the core idea of objectivism. The poems of Williams in this sense can be regarded as the "physical poetry". The vast expanse of the United States offers the poet wealthy materials, he advocated to find writing material in everything from nature, any object, as long as you are good at observing you will be able to write something. Through Williams' poetry, we can find an extensive selection of his works, the ideas expressed are all-inclusive. The poet himself once said "everything is good material for writing poetry”. [1]

\section{B. Experiencing objects by sense}

Poetry must experience object directly through the sense of physical, as a result readers can immediately experience the beauty of sense while reading poems of Williams. Reading Williams' poems, we can easily find his poem 'try the best to embody the essence of poetry, filled with unrestrained enthusiasm, careful observation of everyday life, vivid expression, poetry significance all come from the bottom of the specific sensory experience”. [2] The so-called objective emphasizes on the importance of the object, but ignored the senses to enjoy in the process of writing will dull the things written by poets. It is to write the usual things to make it easier for people to become bored, however focusing on the effect of the senses makes up for the deficiencies.

\section{Taking advantages of skills used in western painting}

Williams draws on Western painting techniques in his poems. In the "Autobiography" Williams tells his own preference for painting: "the painters take a majority part in my circle of friends .In fact, I myself almost become a painter, like my mother tried to do. But later I found that graffiti in the manuscript is much easier than painting on the canvas, so my creation of the painting soon turned to literature. [3] Nevertheless, he still emphasized that "through all my life I have the very strong desire to become a painter". [4] In his poetry, Williams borrowed some creative techniques of Western painting, thus increasing the expressive power of his poetry, as a result making the poetry become more colorful and dynamic.

Through above brief introduction, students have already possessed the knowledge about the theory of Williams' objectivism, esp. known its three features. In the following part, teachers can lead students into the process of analyzing the Objectivism Embodied in Williams’ Poems.

\section{ObJectivism Embodied IN WiLliams’ Poems}

After learning the three features of Williams' objectivism in above section, now in the following parts, it's time for teachers to guide students to apply the theory into practice, i.e. analyzing the objectivism embodied in Williams' six poems.

\section{A. His looking for expressing ideas in objective things}

To illustrate, this point, the teacher can choose Williams' two poems to discuss with students. One is "Between walls", the other is "The Young Housewife".

In "Between walls", at the beginning of the poem the author refers to the hospital, the place where disease is spreading and breeding. Seeing the two words "black" "hospital", people seem to see the uncomfortable things in heart, and the feeling of beauty suddenly disappeared. By using the word "wing", the author makes people think of bird flying in the air immediately. Together with it we think of the broad perspective. The rapid conversion of thinking suddenly turns us into a cheerful atmosphere. Black cinders come into our sight gradually but not as uncomfortable as before. Glass debris scatters on the ground, sparsely. The word "green" makes us feel that maybe the debris is sparkling under the sun light. The author chose this common place, the hospital, and then casually selected one of the humble small corners of the hospital. The scattered shards of glass are common to see, the poet used his own language to contact them together. Several independent objective things existed in a poem, which passed a real presence and beauty to us.

In "The Young Housewife", when seeing the beginning of the poetry, it seems as if we are enjoying a piece of beautiful prose. All scenes can be seen almost every day. There is a young woman, moving around in the room lazily. While watching, it seems as if I am the driving people. I see such a cozy picture by a casual glimpse on the way cycling. Then the young woman went to the side of the road, we seem to hear her voice of calling out a seller-the iceman and the fish seller, whose voice is soft and somewhat shy, because she felt that her dress is not very good. The woman in the author's eyes is just like a fallen leaf. However, when nodding to applaud, the sound of crushing leaves by the running over wheels going so clearly into the ears. First is the appearance of the woman, followed by wood walls, these common scenarios blazed the poet's creating idea. Even a simple movement of buying things around the street gives us the immersive feel under Williams' pen. Starting from the most simple and objective physical, he shows us that without too much modification just by using a wide range of material the poetry can still offers endless charming. Someone has commented on his poetry like this: his 
poetry is the things, people, or scenes of everyday life's "snapshot", [5] what he shows to us is "direct things as we can see," original poetry materials, "There is no explanation or comment”.[6]

\section{B. His experiencing objects by sense}

To illustrate, this point, I still recommend the teacher to choose Williams' two poems to discuss with students. One is "This Is Just to Say", the other is "The Red Wheelbarrow".

About the poem "This Is Just to Say", the reason for Williams to write this poem is very simple. The writer ate the plums in the refrigerator his friends stored without permitting, so he apologizes to his friend, and this comes into the poem. The problem is that if the author just used a few simple words to apologize, then we will have no chance to see such a beautiful short poem. In the beginning of the poem the writer introduced that the plums he had eaten in the refrigerator may be prepared for breakfast by his friend, so he had apology in his heart. In fact there is nothing new until here; however, behind it the crowning touch makes the poem become unique. Sweet and cool, once the two words appear they make us feel that it seems we just see a plate of red plum in front of our eyes, the saliva overflows from our mouth immediately.

As for "The Red Wheelbarrow", there are many people who analyze this poem as an imagist one to study, but I think it's more appropriate to put it here to reflect the sensory effect created by the writer while composing this poem. After the rain air is fresh, there is a red wheelbarrow placed silently at the corner of the courtyard. Naturally we connect it to the blue sky which is very eye-catching, isn't it? In the following line we see the heavy loaded small wheelbarrow gleaming under the sun due to the scouring of rain. Not far away from it, a group of white chickens and the red wheelbarrow form an obvious contrast. Such a bright and beautiful scene unfolds right in front of us. The author brings not only visual impact but also sensory enjoyment.

\section{His taking advantages of skills used in western painting}

Once again, to illustrate, this point, I still recommend the teacher to choose Williams' two poems to discuss with students. One is "Dance", the other is "Daisy".

All the poems of Williams' poetry From 'Brueghel's Great Picture" are based on the paintings of his favorite painter Breugel's painting, and "Dance" is one of them. In this poem, the poet uses real words to express something that the artists want to reveal. This poem is adapted according to one of Breughel's painting titled as 'bazaar". The painting itself tells the scene of some people entertaining in the open-air market. The first sentence tells the dancing people walk around forming a lively scene. Later the instrument sound gradually comes into the ears, and then the poet described the attitudes of the dancers in detail. Their hands swinging, below their feet sliding forward, even the cigarette butts did not escape the eyes of the people, the poet is even concerned that whether the small cigarette butts can afford such a noisy scene. All in all, people are passionate and enjoying unlimited fun. The poet treats the painting as his writing object which fully reflects his soft spot for painting.
The background of creating "Daisy" is like this: When Williams entered the University of Pennsylvania to study medicine, he became an acquaintance of the artist Demuth, and they became close friends. Later he often participates in the New York avant-garde artists' salon, so his poems also received painting thoughts from here. Demuth is also the sticker of cubist painting principles. In his watercolor paintings, Demuth focused on the hearts of yellow flowers, and then used the pen to show the surrounding environment of flowers. At the beginning of the poem the poet mentioned that the daisy plunged into the embrace of the earth freezing the focal point on one focus. We can imagine that a beautiful daisy roots in the soil, tiny but full of force and is so bright. Next we can see the yellow mahogany, and then the perspective moves outward and spreads to the petal, later to the lace. The petals curled slightly, very clear, the only left green makes it more for people to feel the visual contrast. When appreciating the poem, it just seems to tell us how to make paintings not only contain the content but also the beautiful and bright color contrast. Thus the charm of poetry is fully embodied.

\section{CONCLUSION}

From above analysis, we can assert that students must have a profound understanding about the poet and his poems from a new and interesting angle, and know the truth that it is objectivism that brought Williams great fame. As readers can see, objectivism poems show the charming and great skills owned by Williams. When appreciating his poems what we feel is not only words but also moving pictures. Based on the love for his own country he began to find expressing ideas in objective things and common people which becomes the first feature of objectivism. From "Between Walls" we can find that the common place turn to a live and colorful world. After reading this short poem we will be not so sad when thinking of hospital. It's not a place full of death, disease; we can also find something nice here. Experiencing objects by sense is the second feature of objectivism. He observed objects by eyes; however, in the end the picture showed in the poem satisfied all our organs that used to feel things. In "This Is Just to Say" we can feel the plum so real that our saliva betrays our true feeling. The last feature which is also very important is taking advantages of skills used in western painting. When we compare objectivism with cubism in painting we can find they share some common things. The cubism artists like to pursue fragment, resolution and re-combination in the end they use separated screen to show the object they want to paint. In Williams' poems we can also see the skill like this. Like in "The Red Wheelbarrow" we can see separated pieces but in the end what we get is a nice picture.

\section{REFERENCES}

[1] W. Carols Williams. Paterson. New York: New Directions, 1963.

[2] H. James D. the Oxford Companion to American Literature. Oxford: Oxford University Press, 1983.

[3] W. Carlos Williams. Autobiography. New York: New Directions, 1956.

[4] R. Grogan. The Influence of Painting on William Carlos Williams,. London: Cambridge University Press, 1994. 
[5] R. Carolyn et al. Contemporary Literary Critis m. Detroit: Cale Research Co., 1976.

[6] H. Waggoner. American Poets: From the Puritans to the Present. Boston: Houghton Mifflin Co., 1968. 